of Karnataka. This biodiverse area harbours sizeable populations of threatened species such as the tiger and Asian elephant, and endemic species such as the lion-tailed macaque, Ceylon frogmouth and Travancore flying squirrel. The forests of the Western Ghats are one of the main water catchments in India, feeding perennial rivers that sustain a human population of $350-400$ million in the south of the country.

Run-of-the-river power generation is presumed to be environmentally friendly but the impacts of these projects in ecologically sensitive areas are yet to be assessed. Studies of individual projects have documented a number of negative effects on terrestrial and aquatic ecosystems. Although these projects are relatively small their cumulative impact can be considerable, especially if there are numerous projects, such as in the Western Ghats of Karnataka where 72 such projects have been permitted.

Run-of-the-river projects with a power generation capacity capped at $25 \mathrm{MW}$ are eligible for government subsidies. Only above $25 \mathrm{MW}$ is there a compulsory public hearing and an Environmental Impact Assessment prior to construction. To bypass these legal requirements some large single projects have masqueraded as multiple smaller projects. There is also evidence of failures to document the presence of rare, threatened or unique species of flora and fauna where the projects have been implemented, even when species under various schedules of the Wildlife Protection Act 1972 were present.

To halt the detrimental effects of some of these projects Prashant Yavagal, a wildlife enthusiast, and the Western Ghats Environment Forum filed a Public Interest Litigation in the High Court of Karnataka on 3 January 2011. In February 2013, based on ecological evidence presented by the petitioners, such as the location of projects in important wildlife habitats and elephant migratory corridors, the occurrence of threatened species, felling of old-growth trees and cutting of roads on steep slopes (which results in severe soil erosion), the state government withdrew permission formerly given to 10 projects. Later, in April 2013, the existing leases of two projects were cancelled. The government indicated in the court that mini-hydel projects would no longer be permitted within the forests of the Western Ghats of Karnataka. This is a landmark case in a country where there is great pressure for development and enhanced energy generation.

Scientific and technical inputs for the litigation were provided by the Nature Conservation Foundation and Panthera, and several conservation enthusiasts worked collectively to highlight the impacts of these projects on the local wildlife.

POORNESHA H.C. and RASHMI BHAT Nature Conservation Foundation, Bangalore, Karnataka, India.E-mail rashmi@ ncf-india.org

\section{Photographic evidence of the swamp deer in Manas National Park}

The swamp deer (or barasingha) Rucervus duvaucelii is categorized as Vulnerable on the IUCN Red List but the conservation status of its three subspecies, including R. duvaucelii ranjitsinhi of Assam, India, has not been assessed separately. $R$. duvaucelii ranjitsinhi was once common in the Brahmaputra valley in Assam but its populations declined as a result of habitat loss, overhunting, poaching and disease transmitted from cattle. It is now confined to Kaziranga and Manas National Parks. The $500 \mathrm{~km}^{2}$ Manas National Park is the core area of Manas Tiger Reserve and is also a UNESCO World Heritage Site. There is a viable population of the swamp deer in Kaziranga and there were healthy populations of swamp deer in Manas prior to civil unrest in the 1990s, with a population of $>500$ individuals in 1987 . During the civil unrest of 1989-1990, however, poachers almost wiped out the population of swamp deer in Manas.

There have since been indirect reports of the presence of the swamp deer in Manas but no sightings. However, during a joint tiger and prey monitoring exercise carried out by WWF India, Aaranyak, ATREE and the Forest Department, swamp deer were photo-captured twice, on 14 and 23 January 2013, in the Kanchanbari area of the Bhuyanpara range. This proof of the continued existence of the swamp deer in Manas is heartening news. However, a systematic survey is required to determine the status of the population. The UNESCO World Heritage Site committee has advised that a Species Recovery Plan is required, and the Forest Department at the State and Central levels has initiated plans to work for the recovery of this subspecies, in association with other stakeholders.

JiMMY BoRAH, TRIDIP SHARMA, KAMAL AZAD and PALlabi CHAKRABORTY WWF-India, Parbati Nagar Tezpur, Tezpur, Assam, India. E-mail jimmyborah@gmail.com

AnINDYa SWARgowari Manas Tiger Reserve, Assam, India

\section{Declaration of a new sanctuary creates largest protected area network in India}

A new protected area, the $906 \mathrm{~km}^{2}$ Sri Malai Mahadeswara Swamy Wildlife Sanctuary, was declared in May 2013 in Karnataka, southern India. This Sanctuary is part of the Eastern Ghats, where conservation-dependent species such as the tiger, wild dog, Asian elephant and four-horned antelope can be found. The new wildlife sanctuary lies between the $539 \mathrm{~km}^{2}$ Biligirirangaswamy Temple Tiger Reserve and 1,027 $\mathrm{km}^{2}$ Cauvery Wildlife Sanctuary, and the Guttiyalattur, and North and South Baragur multiple-use forests in the state of Tamil Nadu lie adjacent to the 